\title{
“... IN GOD ONLY ONE INFINITE ACT CAN BE THOUGHT ..." THE AMBIGUITY OF DIVINE AGENCY AND THE DIVERSITY OF EVIL
}

\author{
INGOLF U. DALFERTH
}

Claremont Graduate University

\begin{abstract}
The paper argues that God does not act but is creative activity, which helps to overcome evil by the possibilities of the good that it opens up for creatures in the face of evil.
\end{abstract}

\section{DIVINE ACTIVITY VS. DIVINE ACTIONS}

In his Lectures on the philosophical doctrine of religion Kant is reported to have said: „Creation cannot have been other than completed at once in an instant. For in God only one infinite act can be thought, a single, enduring force which created an entire world in an instant and preserves it in eternity. Through this act, many natural forces were poured out, as it were, in this world-whole, which they gradually formed in accordance with general laws. " 1

The implications of this claim are far-reaching. "Fundamentally only one action can be thought in God; for in him there is no succession; but nevertheless this one act may have an infinite number of relations and expressions according to the constitution of the subjects to which it relates, and it actually does have them too. Hence God's power is not at all visible to us at one time while at another it is sensed by us."2

\footnotetext{
${ }^{1}$ Kant (1817: 426).

${ }^{2}$ Ibid. Similarly at other places: "in God only one act can really be thought, which never ceases but expresses itself without variation or interruption. For in God no succession of states takes place, and consequently no time." (Kant 1817: 432.)
} 
Thus, on the one hand Kant agrees with classical theism that God is actus purus, unceasing activity and complete actuality. On the other hand he does not assume different acts or actions of God but only one fundamental, unceasing divine activity. Distinctions presuppose time, and there is no time in God. Divine activity is not in time but makes time and the succession of states possible: Without God, no time, no creation, no actions. But God himself is not in time, nor a part of creation, and hence not somebody (or something) of whom (or of which) we can truly predicate actions. Creation, conservation, salvation, redemption, perfection, consummation etc. are not distinct actions or kinds of actions of God but only one single and unceasing divine activity named differently on the basis of how it affects creation in general or some creatures in particular as this is sensed or conceived by us. Therefore, what we call divine actions are human ways of speaking about the unceasing creative activity we call 'God'. They are our determinations of a divine reality, a human manner of speaking, but they are not distinct divine actions or a divine reality.

Kant was not the only one who argued in this way. Schleiermacher holds the same view. In his treatment of creation and preservation in The Christian Faith, for example, he insists that the traditional talk of divine actions ascribes agency to God in a "too human fashion": ${ }^{3}$ "portraying creation and preservation as distinct kinds of divine activity inappropriately places God within the ,realm of contradictions'“. ${ }^{4}$ When one speaks about God's activity, one is not properly speaking of divine agency or particular divine actions at all but of the divine enactment of creation as a whole. Divine activity is the fundamental reality without which there wouldn't be anything to refer to or the possibility to refer to anything. Divine action talk, on the other hand, is merely a manner of speaking based on our experience, or 'feeling', our sense of God's creative presence in particular circumstances. It brings to light certain features of our human experience, in particular its being grounded in some prior actuality not of our making, but it does not describe a distinct particular divine reality. Theologians, therefore, must be realist about divine activity but not about divine actions or distinct types or kinds of divine activity. They are human manners of speaking that change over time. But divine

\footnotetext{
${ }^{3}$ Schleiermacher (1831: 173).

${ }^{4}$ James (2004: 5).
} 
activity is timelessly actual, indeed, it is that without which nothing else would be possible or could take place.

\section{THE ONTOLOGICAL PRIORITY OF THE POSSIBLE}

All this was not new, of course. Kant and Schleiermacher owed this line of thinking to seminal thinkers of the $17^{\text {th }}$ and $18^{\text {th }}$ centuries, in particular to Spinoza ${ }^{5}$ and to Leibniz, and beyond them to a fundamental change in ontological outlook in medieval theology that paved the way towards modernity: the discovery of 'the ontological priority of the possible. ${ }^{6}$

In Spinoza's metaphysics there are no divine acts; there is only the divine activity of the natura naturans, the creative ground of the natura naturata which is the manifestation of the infinite modes and attributes of the deus sive natura, mind (mental reality) and extension (physical reality) being two of them. Talk of a plurality of distinct divine acts or actions requires a way of distinguishing between them, a way of describing 'creation' in contrast to and distinction from 'preservation' for example. But to draw such distinctions depends on finite contrasts, signs, and language, and this is something we have and use but not God. God is single, abstract and impersonal, the only substance there is, whereas everything else are modes or modifications of its eternal activity. We speak of divine actions, but there is only one divine activity in its infinite expressions and manifestations.

In a different way Leibniz conceived God's divine activity not as a distinct reality alongside created activities nor as the common ground of all created reality but rather as an activity pluralized in the myriads of ways in which monads or individual perspectives on the whole of creation are created, sustained and perfected by God. God's activity works in and through each individual substance or monad in a distinct way. On the one hand it is individualized in the infinite plurality of finite versions and visions of the whole of creation that Leibniz calls 'monads', each reflecting the entire universe in its individual way. On the other hand it is the intrinsic bond that keeps the myriads of monads together within one and the same creation. Each monad is an individual manifestation of divine activity distinct from all others and as such an individual version or microcosmos of the whole of creation. God, the central monad, keeps

\footnotetext{
${ }^{5}$ Cf. Lamm (1996: 127-157).

${ }^{6} \mathrm{Cf}$. a more comprehensive account of this discovery in Dalferth (2014).
} 
all those individual perspectives on everything compossible with each other within the totality of individual perspectives in one and the same universe, and in his infinite goodness, wisdom and power he does so in a way that makes this universe, if not the best world for each of us, then at least the best of all possible worlds for all of us.

Both the creative potency of the natura naturans in Spinoza and the totality of possibilities that strive to become actual in the monads of the best of all possible worlds in Leibniz presuppose the revolution in medieval metaphysics that reversed the ontological order of being and possibility by changing from the priority of the actual over the possible to the priority of the possible over the actual. In the Aristotelian tradition possibility in all its senses was tied to actuality. What is possible differs from what is actual only by being not yet or no more actual: Possibility is possible actuality, actuality takes place in time, and hence all possibility is the possibility of something past, present, or future. Of course, there is an important difference between possibilitas and potentia, between the possibility of something or someone ('It is possible to f') and the potency or competence of something or someone to be or to do something ('It is possible for $a$ to $\mathrm{f}^{\prime}$ ). But both potentia and possibilitas are grounded in being and always the potency and possibility of something actual. There is no potency per se, and there is no genuine possibility that can remain forever unrealized, as the so-called Principle of Plenitude ${ }^{7}$ holds. Aristotelian possibility in all its various senses does not involve reference to simultaneous alternatives but is understood in a statistical or temporal frequency way: Whatever is possible, was, is, or will be actual. ${ }^{8}$

In Metaphysics IX (Theta) Aristotle introduced the modal distinctions in order to be able to describe and analyze the manifold changes in the kosmos. ${ }^{9}$ This helped Christian thinkers to understand becoming in the world, but it was of no help in understanding the becoming of the world, i.e. the creatio ex nihilo. In Aristotelian terms this required postulating not only the possibility of the world but also an actual potency that actualizes that possibility. But the possibility of the world could no longer be understood as the possibility of the actual world but had to be presupposed as possibility: It was no longer a relative possibility but an absolute possibility, a possible absolutum.

\footnotetext{
${ }^{7}$ Lovejoy (1936)

${ }^{8}$ Or in alethic terms: necessary propositions are always true; possible propositions are sometimes true and sometimes false; impossible propositions are always false.

${ }^{9}$ Uckelman (2009: esp. chps. 1, 2 and 3).
} 
The unfolding of this idea led to a completely new paradigm of modal thinking. The possible is no longer defined by reference to the actual in time, the impossible no longer in terms of its incompatibility with the actual world (physical impossibility) or the actuality of the world (metaphysical impossibility). One still holds that there is no possibility, necessity or impossibility as such. But since modalities can no longer be defined as modalities of the actual world, they are seen as being grounded in the divine creator of the world: Absolute possibilities become identified with the eternal ideas in the divine mind. The possibility of the world is understood not relative to the actual world but to the divine mind of the creator. Similarly impossibility is understood independently of any reference to the actual world merely by reference to the creative mind of God: Possible is now everything that is possible for God, i.e. that is made possible by God; and similarly impossible is everything that is impossible for God, i.e. made impossible by God. That is to say, the distinction between the possible and the impossible is no longer dependent on any reference to the created world but solely to God. God is creator as the poet of the possible who distinguishes between the possible and the impossible by making that unique possibility actual from all the simultaneous alternatives before him which best corresponds to God's will for his creation.

This view can be traced back not merely to Duns Scotus in the $14^{\text {th }}$ century but in an important sense to Thomas Aquinas in the $13^{\text {th }}$ century. For Scotus modalities are rooted in the intellect of God. Nothing is possible that is not intelligible and everything that is intelligible receives its being as intelligible in the intellect of God. The totality of intelligible beings make up the various possibilities. However, not all intelligible beings are compossible and can thus be actualized. "Compossibility, understood as logical compossibility, partitions the conceptual space into sets of beings all of which are compossible. One of these sets God actualized, and the others though unactualized are possible." 10

This argument limited the set of possible worlds to those that could be created because they were characterized by logically compossibility. But it did not answer why God created this world rather than any another of the set of non-contradictory worlds. In the $13^{\text {th }}$ century Thomas Aquinas had given an answer to this by arguing that God can indeed "do all things that are possible", i.e. create everything that is free from

${ }^{10}$ Uckelman (2010: 20-21). 
contradiction, and this in an absolute way. ${ }^{11}$ His power is not restricted to the possibilities of the actual world. Yet not everything that is non-contradictory is a factibile for God but only those possibilia whose existence God can will without self-contradiction. Only the possible worlds that correspond to God's good nature and good will are factibile. Since God is good, only what is good can be a factibile for God, and since the summum bonum is one, the factibile must also be one. This not only means that all contingent existence is grounded in the actualizing actuality of God but also that nothing exists that is not willed by God because it is good (or, which amounts to the same, is good because it is willed by God). The actual world is not merely a possibility willed by God to be actual but a possibility willed by God to be actual because it is good - good with respect to its existence (that it is) even if it may not be as good as it could and ought to be with respect to the mode of its existence (how it is). Everything God creates is good because God only wills and creates what is good. The actual world may not be as good as it could and ought to be, but it would not be God's creation if its actuality were not a good willed by God. Any argument for a plurality of possible worlds which God could have created must therefore show that for God there would have been another world that is factibile, i.e. not merely non-contradictory and hence possible, but also such that its actuality would have been compatible with the good will and love of God.

It was precisely this that Leibniz attempted to show to be impossible in his Essais de Théodicée sur la bonté de Dieu, la liberté de l'homme et lorigine $d u$ mal. And just as his arguments were in no way refuted by the facts of the Lisbon earthquake or any other disaster in the world, because they are based not on the goodness of the world but on the goodness of God's creative will, so the singularity of the world cannot be shown by reference to the logically possible but merely by reference to the uniqueness of the creator and the unequivocal definiteness of God's loving will. There may be more than one possible world. But there is only one creation. Hence nothing can be a possible world that is not a part or an aspect of creation, and since God in fact willed this and no other creation, no other possible world could be a factibile because it would be incompatible with the will and love of God.

${ }^{11}$ S. Th. I, q. 25 a. 3 crp.: "Deus dicitur omnipotens, quia potest omnia possibilia absolute". 
This implies a view of God as the ground of all possibility and impossibility. If anything exists at all, it is impossible that nothing exists whatsoever. But whatever exists is possible, and all possibility is the possibility of something actual, as Kant argued in The Only Possible Argument in Support of a Demonstration of the Existence of God, "whether as its determination, or through it as a consequence". "Every possibility presupposes something actual, in and through which everything is given that can be thought." ${ }^{13}$ Or as Kant puts the same point in his Lectures on the Philosophical Doctrine of Religion, "every possibility presupposes something actually given, since if everything were merely possible, then the possible itself would have no ground; so this ground of possibility must itself be given not merely as possible but also as actual." ${ }^{14}$ This is true with respect to every possibility, and that without which there would be no possibility whatsoever, and in particular no possibility of anything free and good, Kant calls 'God'. Or in Kierkegaard's terms who summed up this line of thought: God is "the actuality of the possible"15 the actuality that the good is possible even in the face of evil and despair.

\section{THE TRIUNE ACTIVITY OF GOD}

Kierkegaard's idea of God $^{16}$ does not mean that in God all possibilities are actual or that God is the actuality of both the possibility of good and the possibility of evil: This would make God impossible or ambiguous since not all possibilities are compossible, in particular not good and evil. It rather means that God is God precisely as the one who actualizes possibilities of the good for each of his creatures that enable and empower them to live a life that manifests the love which God is. God is the creative source of everything good by permanently creating, selecting and actualizing possibilities that help to transform his creation into a simile of his divine love. If we seek to unfold this idea of God, we must say a least the following:

${ }^{12}$ Kant (1763: 79): „Alle Möglichkeit ist in irgend etwas Wirklichen gegeben, entweder in demselben als eine Bestimmung, oder durch dasselbe als eine Folge."

${ }^{13}$ Kant (1763: 83): "Alle Möglichkeit setzt etwas Wirkliches voraus, worin und wodurch alles Denkliche gegeben ist."

${ }^{14}$ Kant (1817: 377).

${ }^{15}$ Kierkegaard (1837: 41.21)

${ }^{16}$ In what follows I analyze an idea of God and do not offer a (pseudo-)description of God. To blur that distinction is to slide from theology or philosophy into idolatry. 
(1) God does not act but is unceasing creative activity (semper et ubique actuosus).

(2) God's activity is creative by continuously distinguishing between the possible and the impossible in a temporal process of actualization that creates a reality that is in principle distinct from God and not necessarily compatible with or in correspondence with the love of the creator.

(3) God's creative activity is threefold: God makes the possible possible and therewith the impossible impossible (God is the poet of the possible); God selects from the possible that which can actually become actual because it is compossible with his actuality and hence good (the factibile) by distinguishing it from that which can't because it isn't good (God defines the range of what actually can become actual at any given time because it is good); and God corrects and cultivates the actual by opening up possibilities that are not implied in it (God directs creation towards what is good for his creatures by the possibilities which he makes available to them beyond those which creatures can access in and from their actual states by themselves).

(4) God's threefold creative activity is a threefold good: It is good that something is possible rather than nothing; it is good that some possibilities can become actual rather than others because they are compossible with God's actuality and hence good; it is good that at any given time more becomes possible than that which has already become actual or is implied in it and hence enlarges the range of real possibilities of created actuality that are good for it. The first shows that it is a good thing that creation is possible (it is good that there can be a creation because God is creator); the second shows that it is good that there actually is a creation (it is good that there is something rather than nothing); the third shows that the actual state of creation can and ought to be better than it in fact is (it is good that the way in which creation is can and ought to be better than it is).

(5) Everything possible has an intrinsic tendency, compulsion or urge for becoming actual, and it does become so if it isn't stopped from becoming actual by some other possibility that contradicts it.

(6) Only that which is not contradictory but compossible can become actual, but not everything that is compossible does become actual, 
and not everything that has become actual is something that is compatible with God's love.

(7) Only those compossible possibilities that are compatible with God's love can become actual through God, but since every possibility also implies the possibility of its negation, that which is actually actual is not necessarily compatible with God's love or deserves to be called God's good creation.

(8) Actual reality is deeply ambiguous and always at best on the way to becoming God's good creation by overcoming those aspects that contradict God's love and by increasing and strengthening those aspects that are compatible with or manifest God's love.

(9) What is good or evil for God does not necessarily coincide with what is good or evil for God's creatures, and vice versa. We may (mis)take to be good for us what is evil from God's point of view (i.e. separates us from God's love). And we may (mis)take to be evil for us what in fact is not evil for God (i.e. does not separate us from God). This is why the difference between the old (evil for God) and the new (good for God) in creation is not a difference that can be experienced by creatures. The distinction is not a phenomenological given but a judgment about the given in the light of the distinction between what is good or evil for God.

(10) The way in which God creates makes it necessary to distinguish between what God creates and what becomes possible through what God creates both in a positive sense (by being implied in it) and in a negative sense (by becoming possible through it without being implied in it). God cannot select some compossibilities to become actual (those compatible with God's love) without also making the negation of those possibilities possible (and hence that which is incompatible with God's love).

(11) God's creative activity differentiates at each moment between the merely possible (logical possibility) and the really possible (real possibility) relative to the actual state of creation, and between that which corresponds to God's love in what actually becomes actual (the new) and that which doesn't (the old). Just as God's love is the principle of the possibilities that can and ought to become actual in creation, so the actual state of creation is the principle that defines the range of real possibilities at any given moment of creation; and just as God's love not merely creates possibilities but also makes it 
possible to negate those possibilities, so the actual state of creation not only corresponds to God's love but also manifests that which contradicts God's love.

(12) God's goodness is that God creates what is good for his creatures by overcoming what is evil for God in creation and thus undermines the compatibility of divine and created life: God's goodness is the principle of selecting from the totality of possibilities compatible with God's love at any given time (the factibile) the set of real possibilities that are in principle compatible with the actual state of creation without being merely implied in it. Since positing those real possibilities also makes their negation possible, God's goodness is creative not by directly determining what becomes actual but by opening up the actual state of creation towards those possibilities that are not (yet) actual but ought to become actual in order to decrease the incompatibilities (the old) and increase the compatibilities between the love of God and the actual state of creation (the new).

(13) God overcomes that which is evil for God in creation (the old) by making it possible that not further evil but something good for his creatures follows from it (the new) - and it will be a different good for the victims who have suffered evil and the perpetrators who have committed evil.

(14) God achieves the good for his creation because he is in complete control of the goodness of the outcome of his divine activity. Whereas creatures cannot safeguard that the good they intend will not result in evil, God has control over the goodness of the effects of his activity. Creatures share with their creator that to be is to be active, but they differ from God in that their being is contingent and a gift from their creator, and that they cannot guarantee the goodness of their actions. They are, to a limited degree, the cause of the effects of their actions, but they are not the cause of the goodness of those effects. They may intend the good, but they cannot guarantee that what they do will be good rather than evil.

(15) Only God is free, not because he can choose (between good and) evil or because he has the capacity to resolve by his "own volition, two or more possible courses of action into one actual course of 
action"17 but because he is in complete control of the goodness of the outcome of his activity. Creatures, on the other hand, who can and do choose (between good and) evil and have the self-determining power to do the one rather than the other of two or more possible courses of action, are not free in the relevant sense because they cannot guarantee that the good they intend will actually be achieved. Truth, freedom and goodness are divine determinations or attributes and true of creatures only in so far as they are made true, free and good by God.

\section{THE DIVERSITY OF EVIL AND THE LOVE OF GOD}

This brings me, finally, to evil. How is it possible, within such a framework of thought, to understand how God prevents or overcomes evil? ${ }^{18}$ To ask this question is to assume that there is evil (which nobody will deny), and that God has something to do with it (which is far from clear). Reference to God does not help to explain the fact of evil, and the fact of evil does not necessarily count against God as we know from centuries of intense debate. If theology relates God and evil at all, then not in order to explain evil by reference to God or to question God by reference to evil, but in order to help people to live a human life in the face of inexplicable and meaningless evil. There is no meaning to be discovered in the meaningless, and recourse to God in religious discourse is not part of explaining evil but of helping people suffering from evil to re-orient their lives and find a way back into a meaningful life in the face of the meaningless. This is what theology ought to unfold and what philosophy must seek to understand. I begin by clarifying the notion of evil. ${ }^{19}$

\section{What is evil?}

The first thing to be noted is that to understand something as evil and to understand evil as something must not be confused. It is one thing to identify tokens of evil, i.e. describe what is evil for somebody in a given

\footnotetext{
17 Boyd (2014: 4).

${ }^{18}$ My assignment was to speak on Divine Action, Theodicy, and the Possibility to Prevent Evil. All three notions are highly obscure, and combining them is not enough to overcome their lack of clarity.

19 In the following I make use of what I have written in Dalferth (2006), (2008); (2010); (2011); (2014).
} 
context, quite another to outline a theory of evil, i.e. give an account of what evil is. Most philosophical and theological conceptions of evil are concerned with the latter. In the Western tradition we find three major answers that cannot easily be combined: evil is understood as privatio boni, or as malefactum, or as peccatum, i.e. lack of faith and rejection of the gift of God's love. Instead of starting with them, I shall begin by looking at the structure of particular tokens (acts or facts) of evil.

Wherever there is an evil, it makes sense to ask:

(1) What has happened? (occurrence);

(2) To whom has it happened? (victim);

(3) How does he or she experience it? (actual valuation from a firstperson perspective);

(4) How ought it to be judged? (normative valuation from a thirdperson perspective).

To distinguish these questions is important for a number of reasons.

First, to explain the occurrence is not to explain the evil in question but only that which gives rise to the experience of evil. Occurrences in nature and history have empirical or historical explanations. But those explanations do not show the phenomena in question to be evil unless we add the further premise that it would have been better (for those concerned, or others, or us) if they had not occurred.

Second, to give reasons for the valuation is not to explain the occurrence. The reasons why we think abusing a child is wrong do not explain what has happened but only make plain why we think it is evil. Conversely, to explain the occurrence does not tell us anything about how it should be judged or valuated. This is why empirical, historical, economic or political explanations of evil are not enough. They tell us, if successful, why things have happened in the way they did, and perhaps how those involved (victims and perpetrators) understood what happened to them or what they did, but they don't tell us how we should look at what has happened or how we should understand human life or ourselves in the light of what has happened. Not only is there a difference between giving reasons and stating causes, there is also a difference between describing and explaining and judging and evaluating an occurrence or a situation. Just as knowing what is the case does not tell us what to do, so knowing our value orientations does not explain the occurrence of a given evil, but only why we think it is evil. 
Finally, the difference between the third and the fourth question is important because it is one thing to be a victim of evil, another to reflect on evil. Of course, victims can and do reflect on their own suffering, and they do so from a first-person perspective. But this only underlines the difference between their view of their situation and someone else's view of it, which may but need not coincide. We want to say that slavery is evil even if those enslaved don't think so; and we want to say that husbands who batter their wives do wrong or commit evil even where their wives don't complain. On the other hand, in judging the situation and the suffering of others, we must be careful to take into account how they themselves perceive it. If we think it is evil and they don't, or if we think it isn't evil but they do, we need to give reasons for our view and listen carefully to theirs, and if they reject the way we evaluate their situation, we must be careful not to force a view on them which they have reasons not to hold or, conversely, withhold our views, not name the evil in question, and thus not help them to become aware of the evil in which they are involved.

\section{Evil, good and God}

Against the backdrop of this differentiated understanding of evil »God is good « can mean a number of different things, namely: (1) God is totally different from anything bad or evil; or (2) God has delivered his people from evil; (3) God fights evil; (4) God has overcome evil; or (5) God overcomes evil not by some counter-evil but by creating something good out of evil. In the first case, God's goodness marks the difference between good and evil; in the second his goodness towards his people; in the third the antagonism between good and evil; in the fourth the victory of the good over evil; and in the last the mode of this victory: the good is achieved not merely by fighting evil but through fighting it by creating good out of evil and ending evil through good.

These senses have to be distinguished because they go with different schemes of orientation, have different implications, and correspond to different understandings of evil. Accordingly, evil is seen as that which is incompatible with God; or actively opposing God; or has been overcome by God; or is incompatible with God's way of doing things, with the mode of God's activity. In the first case God is totally different from everything else by being wholly and solely good; in the second and third God's 
goodness is the divine activity of fighting against evil; in the fourth case 'good ' is seen as a success term when applied to God; and in the last 'good « is a modal term for the way in which God overcomes evil: not by committing some other (greater) evil but by doing something good.

These understandings of evil are the outcome of processes of theological reflection that paradigmatically comprise the following steps.

In an experiential or phenomenological sense evil is everything that harms or humiliates a person. This can involve many things, from the obvious sufferings involved in illness, disasters and evildoing which nobody will and can deny to be evil, to the more subtle cases which have taken centuries to be described and acknowledged as evils (slavery, exploitation of women, child labor, emotional abuse at the workplace).

When these phenomena are seen and evaluated from a religious (Jewish, Christian, Muslim) perspective, the result is a religious sense of evil: Evil is everything that is contrary to God's will, i.e. - in Christian terms - everything that contradicts the rule of love of God and one's neighbor. Everything that is contrary to God's will separates human beings from God and thus contradicts their distinction as God's creatures made for a special relationship of mutual love with God and one another.

Thus, the decisive question for coping with the problem of evil in actual religious practice becomes how we can know God's will and plan for his creation. The monotheistic religions give different answers to this. Jews point to Moses and the Torah, Christians to Jesus and the gospel, Moslems to Mohammed and the Koran. The difference is not merely that each religious tradition names a different authority and communicator of God's will, but also that in the respective theological traditions God's will is often construed in moral or even juridical terms as a set of divine commandments as to what humans ought or ought not to do.

But this results in a misleading moralizing view of evil: Everything that fails to comply with what are taken to be God's commandments is then seen as evil. This misses the point of the Torah, the gospel, and arguably also the Koran. They are not sets of divine prescriptions, commandments and prohibitions, which humans must obey solely because God has commanded them. This would be heteronomy at its worst and create an abyss between God's will, God's justice and God's mercy. They are rather to be understood as God's gift of a blueprint of a good and just human life in community with God and one another, the presentation not of what God demands of his creatures but what God has done for them in enabling and empowering them to live their life no longer way below its best. They 
outline a way of life that responds in gratitude to the goods received from God rather than to a set of arbitrary divine commandments and prohibitions that are to be obeyed on pain of punishment.

In short, against the backdrop of God's will thus understood, evil is in a strict theological sense that which God overcomes by the good he creates for His creation. The point of evil is not to ignore a divine command but to obscure a divine gift. In all monotheistic religions the best thing for God's creatures is not to be cut off from the divine source of life, i.e. God's creative and redemptive love which enables humans to live a truly human life.

This understanding of evil is not simply coextensive with what harms or humiliates humans. It includes evils done to and suffered by other creatures, and it does not in principle exclude all human suffering as evil. Not everything we suffer cuts us off from God. Just as not every possibile is a factibile, so not every evil experienced by someone is an evil that separates from God's love and hence an evil overcome by God. From a Christian perspective this does not include death, for example, and it does not include all types of suffering. A world without evil is not a world without suffering but rather a world without suffering that is evil because it cuts humans or any other creature off from God's love.

\section{The modal status of evil}

For biblical monotheism it is not enough to say that God is not the source and cause of evil. In contrast to the cosmotheological monotheisms of the Hellenist philosophies, biblical monotheism holds not only that there is only one God, but also that God's relation to the world is creation rather than correlation, i.e. that there was a time when the world was not, and that evil is a contingent fact that could and should be otherwise. Thus, the situation is the following:

\begin{tabular}{c|l|c|l}
\hline \multicolumn{2}{c|}{ Cosmotheological monotheism } & \multicolumn{2}{|c}{ Creation-theological monotheism } \\
\hline (1) & There is only one God & $(1)$ & There is only one God \\
\hline (2) & $\begin{array}{l}\text { God is the first and ultimate prin- } \\
\text { ciple of everything good }\end{array}$ & $(2)$ & $\begin{array}{l}\text { God is the Lord of creation, histo- } \\
\text { ry, and all people }\end{array}$ \\
\hline (3) & $\begin{array}{l}\text { God's relation to the world is corre- } \\
\text { lation or emanation, the world's } \\
\text { relation to God is participation }\end{array}$ & $(3)$ & $\begin{array}{l}\text { God's relation to the world is crea- } \\
\text { tion, conservation, and perfection, } \\
\text { the world's relation to God is } \\
\text { dependence }\end{array}$ \\
\hline
\end{tabular}




\begin{tabular}{l|l|l|l}
\hline (4) & $\begin{array}{l}\text { It is impossible that there is } \\
\text { a world but no God, or that there } \\
\text { is God but no world }\end{array}$ & (4) & $\begin{array}{l}\text { It is impossible that there is a world } \\
\text { but no God, but it is possible that } \\
\text { there is God without a world }\end{array}$ \\
\hline (5) & $\begin{array}{l}\text { The world is the totality of things } \\
\text { and events }\end{array}$ & (5) & $\begin{array}{l}\text { Creation is the totality of actions } \\
\text { of finite and infinite agents. }\end{array}$ \\
\hline (6) & God is apathetic & $(6)$ & God is pathetic \\
\hline (7) & $\begin{array}{l}\text { It is a necessary fact that there is } \\
\text { evil in the world: A world without } \\
\text { evil is impossible }\end{array}$ & (7) & $\begin{array}{l}\text { It is a contingent fact that there is } \\
\text { evil in the world: A world without } \\
\text { evil is possible }\end{array}$ \\
\hline
\end{tabular}

Thus, whereas on each side a given individual evil can be a contingent evil that could not have been, there is a deep difference with respect to the fact that there is evil at all in the world and how evil is to be understood as privatio boni or as malefactum. For the cosmotheological tradition the privatio boni view is intimately bound up with the very idea of the cosmos, which differs from God precisely because God alone is totally and exclusively good whereas everything different from God is a mix of good and evil. In this view there is no way of overcoming evil as long as there is a world different or at least distinct from God. But this is more difficult for biblical monotheism and its understanding of the world as creation and of evil as malefactum. For if God is the sole creator of everything, whence evil?

Two possible answers are ruled out in principle: First, evil does not originate from God. If it did, God would become ambiguous and recourse to God in times of trouble religiously useless. Second, evil does not originate from some anti-God. Manichean views of an anti-God as the originator of evil are not only incompatible with a strict view of creation but also fail to explain anything: they re-state the problem but do not solve it. However, if God is good and the only God and Creator of everything different from God, how can there be evil in the world?

The standard answer is that it is an unavoidable consequence of created free will (free will defense). But even if the free will defense works for some cases, it does not work for all cases. Indeed, the good of a created free will that not only can choose between good and evil but must do so and in fact chooses evil in no way outweighs the evil of a single child dying of HIV or cancer. It is adding to the amount of evil in the world even to attempt to answer the problem in this way. The correct answer is rather that we have asked the wrong question. We have to construe the problem the other way round: What is surprising is not that there is evil 
in the world (this we all know) but that this world is God's creation and that the creator is good (this we all have to discover). The surprising facts are God's goodness and the createdness of the universe, and in the face of evil this poses the problem how God comes to be known to be good and how the world is disclosed to be God's good creation without denying or downplaying the reality of evil.

\section{Ways of preventing evil}

As we have seen, for something to be an evil there must be an occurrence that causes suffering (an event in life); somebody who suffers (a victim); and an (implicit or explicit) appraisal or valuation of this suffering as evil, i.e. as something that is disapproved by a moral observer (a valuation). The first underlines that without life, there is no evil: A world without life is a world without evil. The second that without victims who suffer, there is no evil: A life in which nobody suffers is a life without evil. The third that without experiencing suffering and pain as evil, there is no evil: In a life in which suffering and pain are not experienced as evil, there is no evil.

This indicates some obvious ways of bringing evil to an end. The radical solution is: End life! Since without life there is no evil, the radical way of overcoming evil is to bring life to an end - in a particular case or life on earth as such. The cultural solution is: Improve life and end suffering! Since there is no evil where there is no suffering, an important way of containing evil is to fight and restrict suffering as we attempt to do in medicine, psychology, law, technology, education etc. The existential or hermeneutical solution is: Understand suffering differently! Since there is no evil where suffering is not experienced or valued as evil, the existential way of overcoming evil is to change our understanding or interpretation of suffering. We may not be able to stop all suffering, but (in many cases) we can change our attitude towards it and look at it not as evil any more.

The three maxims End life, End suffering, and Understand suffering differently obviously raise very different problems. But they indicate three possible eschatological scenarios of a world without evil: A world without life; a world with life but without suffering; and a world in which suffering is no longer experienced as evil. The first is not an unlikely future given the actual state of our world. The second is impossible as long as life feeds on other life. The third is not impossible but most difficult to 
achieve for bodily creatures such as us whose attitudes are determined by emotions, and whose emotions are not governed by reason alone.

\section{God and evil}

What follows from this for the question of how God prevents or overcomes evil?

(1) Not everything that is an evil for us is also an evil that separates us from God. If God overcomes the evil that separates his creatures from their creator, then not everything evil for us is an evil that needs to be overcome by God.

(2) There is evil that we can and ought to avoid. There is evil committed which cannot be made undone. There is evil we cannot understand and have to learn to live with. End Suffering (where you can) and Understand suffering differently (if you can) are maxims that point the way. But given our human predicament, we cannot stop all suffering or understand all suffering that cannot be avoided differently. With respect to evil, we are not in control of what we do. We cannot guarantee that the good we intend will not result in evil, or that the evil we do will not lead to something good.

(3) We are the cause of the effects of our actions. But we are not the cause of the goodness of our actions. If what we do is good, it is good because God makes it good by judging it to be good. And if what we do is evil, then it is not we but God who turns the consequences of evil into something positive or good.

(4) God is good by making us good; and God makes us good by turning the evil we do and the evil we suffer into something that does not endlessly bring forth further evil but rather something good in ways that cannot be foreseen. ${ }^{20}$

(5) There are many notions of free will and of evil. But with respect to evil in the theological sense, i.e. that which separates creatures from God and is overcome by the good which God does for his creatures, the decisive notion of free will is a will that is in control of the goodness of the outcomes of its actions. Only God is free in this sense, not human beings. If the evil that separates us from God is overcome at

${ }^{20}$ Schiller (1799: V,1): "Das eben ist der Fluch der bösen Tat, // Daß sie, fortzeugend, immer Böses muß gebären." - "This is the curse of every evil deed // That, propagating still, it brings forth evil" (transl. S. T. Coleridge). 
all, then it is overcome solely by God and not by us - by what God does for us and not by what we do for God.

(6) The appropriate Christian attitude to evil is not a version of the so-called 'free will defense' but the well-founded hope that God will secure what we cannot achieve even where we try hard: that evil is overcome by good - a good that will be different for the victims and for the perpetrators of evil.

\section{BIBLIOGRAPHY}

Boyd, Gregory A. 2014. 'Free Will, The Future and Divine Assurance. Responding to Three Common Objections to the Open View', MS. pp. 1-12

Dalferth, Ingolf U. 2006. Das Böse. Essay über die kulturelle Denkform des Unbegreiflichen (Tübingen: Mohr Siebeck, 22010)

Dalferth, Ingolf U. 2008. 'The Contingency of Evil', Archivio di Filosofia LXXV 2007. pp. 251-274

Dalferth, Ingolf U. 2010. Malum. Theologische Hermeneutik des Bösen (Tübingen: Mohr Siebeck)

Dalferth, Ingolf U. 2011. 'Die Kontingenz des Bösen', Ingolf U. Dalferth, Karl Lehmann \& Navid Kermani, Das Böse. Drei Annäherungen (Freiburg i. Br.: Herder), pp. 9-52

Dalferth, Ingolf U. 2014. 'Possibile Absolutum', Anselm K. Min (ed), Rethinking the Medieval Legacy for Contemporary Theology (Notre Dame: University of Notre Dame Press), pp. 91-130.

James, Thomas. 2004. 'Schleiermacher on divine action' http://www.academia. edu/4249563/Schleiermacher_on_divine_action

Kant, Immanuel. 1763. 'Der einzig mögliche Beweisgrund zu einer Demonstration des Daseins Gottes', Vorkritische Schriften II: 1757-1777 (AA II, 63-163)

Kant, Immanuel. 1817. 'Lectures on the philosophical doctrine of religion', Allen W. Wood \& George di Giovanni (eds), Religion and Rational Theology (Cambridge: Cambridge University Press), pp. 335-452

Kierkegaard, Søren. 1837. Journal AA:22 (1837), in: SK Skrifter vol. 17 (Copenhagen 2000)

Lamm, Julia A. 1996. The Living God: Schleiermacher's Theological Appropriation of Spinoza (University Park, PA: Penn State University Press), pp. 127-157

Leibniz, Gottfried Wilhelm. 1710. Essais de Théodicée sur la bonté de Dieu, la liberté de l'homme et l'origine du mal (Amsterdam)

Lovejoy, Arthur O. 1936. The Great Chain of Being. A Study of the History of Idea (Cambridge: Harvard University Press)

Schiller, Friedrich. 1799. Die Picolomini http://www.zeno.org/Literatur/M/ Schiller,+Friedrich/Dramen/Wallenstein/Die+Piccolomini 
Schleiermacher, Friedrich. 1831. The Christian Faith, ed. by H. R. Macintosh \& J. S. Stewart (Edinburgh: T. \& T. Clark 1999)

Thomas Aquinas. Summa theological, http://www.corpusthomisticum.org/ sth0000.html

Uckelman, Sara L. 2009. Modalities in Medieval Logic, ILLC Dissertation Series DS-2009-04 (Institute for Logic, Language and Computation, Universiteit van Amsterdam) 